Geissmann, T., 1991: A reassessment of age of sexual maturity in gibbons (Hylobates spp.). American Journal of Primatology 23: 11-22.

\title{
A Reassessment of Age of Sexual Maturity in Gibbons (Hylobates spp.)
}

\author{
THOMAS GEISSMANN \\ Anthropological Institute, Zürich University, Switzerland
}

From studies of both wild and captive animals, gibbons are thought to reach sexual maturity at about 6 to 8 years of age, and the siamang (Hylobates syndactylus) at about 8 to 9 years. However, a review of the literature reveals that in most cases the exact age of the maturing animals was not known and had to be estimated. This study presents seven case reports on captive gibbons of known age. Captive males of the white-cheeked crested gibbon ( $H$. leucogenys leucogenys) and of the siamang (H. syndactylus) can breed at the age of 4 and 4.3 years, respectively. Similarly, hybrid females $(H$. lar x H. moloch) and siamang females can breed at 5.1 and 5.2 years, respectively. This finding may help to improve the breeding success of captive gibbon populations. It is not clear whether gibbons reach sexual maturity earlier in captivity or whether sexual maturity is also reached by five years of age in the wild. Possible implications for the interpretation of group size regulation and of reproductive strategies of wild gibbons are discussed.

Key words: gibbons, siamang, sexual maturity, Hylobates syndactylus, Hylobates leucogenys leucogenys, Hylobates lar x H. moloch

\section{INTRODUCTION}

Field studies on gibbons (Hylobates spp.) have suggested that sexual maturity is attained at the age of about 6 years in $H$. lar and $H$. klossii [Ellefson, 1974, p.89; Tilson, 1981, p.263], between 6 and 8 years in H. hoolock [Tilson, 1979, p.14], and between 8 and 9 years in H. syndactylus [Chivers, 1974, p.234]. Gibbons are thought to be "not fully independent until 7 or 8 years of age" [Gittins \& Raemaekers, 1980, p.68].

Reports on captive gibbons seem to be consistent with the field data. Although some indications suggest that captive gibbons may begin to mature sexually before the age of six years [Brody \& Brody, 1974; Delacour, 1951], in none of these publications was the exact age of the animals known, and the latter study does not explain what observable change was taken as indicating the onset of sexual maturity (e.g. changes in the color of the fur, first copulation, onset of menstruation, birth of first offspring).

Received for publication April 12, 1990; revision accepted August 14, 1990.

Address reprint requests to Thomas Geissmann, Anthropological Institute, University Zürich-Irchel, Winterthurerstrasse 190, CH-8057 Zürich, Switzerland. 


\section{2 / Geissmann}

Times of color changes occurring in subadult females of $H$. concolor [Fischer, 1980; Pocock, 1905], H. leucogenys [Delacour, 1951; Deputte \& Leclerc-Cassan, 1981; Dittrich, 1979], and H. hoolock [McCann, 1933; Peart, 1935], and in subadult males of H. pileatus [Brockelman, 1975; Dobroruka, 1979; Gray, 1861; Marshall \& Sugardjito, 1986] are sometimes equated with the onset of sexual maturity [e.g. Delacour, 1951; McCann, 1933]. It remains to be demonstrated that this is justifiable. In females of $H$. leucogenys leucogenys, "color change seems to begin some time before sexual maturity, but it may occur afterwards" [Deputte \& Leclerc-Cassan, 1981]. Likewise, the onset of sexual activity or the onset of menstruation would seem to be problematic as an indicator of sexual maturity. In captive male baboons (Papio cynocephalus) and in female talapoins (Miopithecus talapoin), for instance, sexual activity was observed to occur several years earlier than actual reproduction [Lister, 1975; Rowell, 1977]. A period of "adolescent sterility" in females between the onset of menarche and the time of first conception has been reported in many primates [Richard, 1985, p.222], for instance in talapoins [Rowell, 1977] and in chimpanzees (Pan troglodytes) [Goodall, 1986]. Rowell [1977, p.285f] considers age at first conception a biologically more relevant index of female reproductive maturity.

This study presents seven case reports as evidence that captive males of the northern white-cheeked crested gibbon ( $H$. leucogenys leucogenys), males and females of the siamang (H. syndactylus) and female hybrids ( $H$. lar $\times$ $H$. moloch), at least, can reach sexual maturity well before six years of age. This finding may have some importance for the improvement of the breeding success of captive gibbons. In addition, possible implications for the interpretation of group size regulation and of reproductive strategies of wild gibbons are discussed.

\section{MATERIAL AND METHODS}

Data presented in the case reports were collected from zoological gardens in Czechoslovakia, East Germany, Switzerland, and West Germany in the course of a study on gibbon communication. For animals cited in previous reports [Geissmann, 1986, in press], the same abbreviations of names have been used in order to facilitate crossreferences.

As recommended by Rowell [1977], age at first conception was used as an index of sexual maturity. In order to permit direct comparison between data on the age of sexual maturity in gibbons presented in this report and data from the literature, age at birth of the first offspring is also given. The age at attainment of sexual maturity using this method can be calculated by subtracting gestation length from the age at birth of the first offspring.

Comparative data on birth weight in siamangs was needed for the second case report. Little information is available on this [Anonymous, 1976; Eisenberg, 1981; LaMalfa, 1969; Rumbaugh, 1967; Schultz, 1972], and even some of these data are questionable: A handwritten note in the A.H.Schultz-Archive (Anthropological Institute Zürich) documents that the three birth weights published in Schultz [1972] were taken from preserved specimens. Eisenberg [1981] published a (mean?) birth weight for the siamang, but does not indicate how many individuals had been weighed. LaMalfa [1969] published weights of four newborn siamangs, but the the lowest weight of $6 \mathrm{oz}$ was a printing error and should have read $16 \mathrm{oz}(454 \mathrm{~g})$ [LaMalfa, pers. comm. 1988]. Therefore, data for 23 birth weights of individual siamangs were obtained from several zoos in England (Twycross), Germany (Dortmund, Duisburg, Frankfurt, Krefeld), Switzerland (Zürich), and the U.S.A. (Milwaukee). To these were added two individual birth weights from the literature [Anonymous, 1976; Rumbaugh, 1967]. 
Table I. Ages of Captive Gibbons at Birth of First Offspring: Data From the Literature

\begin{tabular}{|c|c|c|c|c|c|}
\hline \multirow[b]{2}{*}{ Species } & \multicolumn{2}{|c|}{$\begin{array}{c}\mathrm{N} \\
\text { (in- } \\
\text { divi- } \\
\text { duals } \\
\text { ) }^{\mathrm{a}}\end{array}$} & \multicolumn{2}{|l|}{$\begin{array}{c}\text { Age of } \\
\text { indi- } \\
\text { vidual at } \\
\text { birth of } \\
1 \text { st } \\
\text { offspring } \\
\left(_{(y r)}\right)^{b}\end{array}$} & \multirow[b]{2}{*}{ Reference } \\
\hline & $\mathrm{M}$ & $\mathrm{F}$ & 1 & 2 & \\
\hline $\begin{array}{l}\text { H. leucogenys } \\
\text { leucogenys }\end{array}$ & 1 & 1 & & Ca. 7.5 & Adler et al. [1988] \\
\hline $\begin{array}{l}\text { H. leucogenys } \\
\text { leucogenys }\end{array}$ & 1 & 1 & & 9 & Dittrich [1979] \\
\hline H. lar & & 14 & & Ca. 6-9 & Kawakami and Kollias [1984] \\
\hline H. lar & & 1 & Ca. 6.6 & & Schessler and Nash [1977] \\
\hline H. lar & & 1 & Ca. 7 & & Kollias and Kawakami [1981] \\
\hline H. lar & & 1 & & Ca. 7+ & Sawina and Opachowa [1981] \\
\hline H. lar & 1 & 1 & & Ca. 8 & Haggard [1965] \\
\hline H. $\operatorname{lar} c$ & & 1 & & Ca. $8.8-9.8$ & $\begin{array}{l}\text { Meyer-Holzapfel [1950]; } \\
\text { Steiner [1947, 1949] }\end{array}$ \\
\hline H. lar & & 1 & & Ca. 9 & Poglayen-Neuwall [1977] \\
\hline H. lar & & 1 & 9.82 & & Haggard [1965] \\
\hline H. muelleri & 1 & & & Ca. 6.8 & Brody and Brody [1974] \\
\hline H. muelleri & & 1 & & Ca. 7.3 & Brody and Brody [1974] \\
\hline H. pileatus ${ }^{c}$ & 1 & & & Ca. 8.8-9.8 & $\begin{array}{l}\text { Meyer-Holzapfel [1950]; } \\
\text { Steiner [1947, 1949] }\end{array}$ \\
\hline H. syndactylus ${ }^{d}$ & & 1 & & Ca. 5.3-8.3 & $\begin{array}{l}\text { Fox [1972, 1977, 1984]; La } \\
\quad \text { Malfa [1969] }\end{array}$ \\
\hline H. syndactylus & 1 & & & Ca. 6.1 & Bennett [1976] \\
\hline H. syndactylus & & 1 & & Ca. 7.4 & Bennett [1976] \\
\hline H. syndactylus & 1 & 1 & & Ca. 8 & Bartmann and Brahm [1980] \\
\hline H. syndactylus & & 1 & 8.25 & & Haimoff [1981] \\
\hline H. syndactylus & 1 & & & Ca. 10 & La Malfa [1969] \\
\hline
\end{tabular}

${ }^{\mathrm{a}} \mathrm{M}=$ males; $\mathrm{F}=$ females.

b 1 = age known; 2 = age estimated; $y=$ years.

${ }^{c}$ The gibbon pair studied by Steiner [1947, 1949] and Meyer-Holzapfel [1950] can be identified as a male $H$. pileatus and a female $H$. lar, based on the published photographs. The age of both animals upon their arrival at the zoo was estimated to be 4 years in one report [Steiner, 1949], and 3 years in the other two reports [MeyerHolzapfel, 1950; Steiner, 1947]. The male was still in the process of colour change when his first offspring was born. Personal observations on maturing pileated gibbons favor use of the younger age estimate.

${ }^{\mathrm{d}}$ The age of this siamang female was estimated upon her arrival at the zoo to be 3 or 4 years [see Fox, 1972, 1977, 1984], and 6 years by LaMalfa [1969], hence the large range for this animal in the table. In addition, the reported date of arrival at the zoo differs by 28 days between the two authors.

In this report, black crested gibbons, H. concolor, and light-cheeked crested gibbons, $H$. leucogenys are regarded as two distinct species. This view is based on anatomical differences between H. concolor and H. leucogenys (Ma and Wang, 1986; Ma et al., 1988). In addition, overlapping distribution of $H$. concolor and $H$. leucogenys has been reported for two localities in northern Vietnam (Dao Van Tien, 1983) and for one in southern Yunnan Province in China (Ma and Wang, 1986; Ma et al., 1988).

\section{RESULTS}

Table I summarizes data collected from the literature on the age of gibbons at the birth of first offspring. Data (also collected from the literature) on the duration of gestation in gibbons are listed in Table II. For the sake of brevity, the 


\section{4 / Geissmann}

TABLE II. Gestation Lengths in Gibbons

\begin{tabular}{|c|c|c|c|}
\hline Species & $\begin{array}{c}\mathrm{N} \\
\text { (preg- } \\
\text { nancies) }\end{array}$ & Duration (days) & Reference \\
\hline $\begin{array}{l}\text { H. leucogenys } \\
\text { leucogenys(?) }\end{array}$ & 1 & (ca. 7 months) & Rode [1942] \\
\hline $\begin{array}{l}\text { H. leucogenys siki or } \\
\text { H. gabriellae }\end{array}$ & 1 & $200-212$ & Olivier [cited in Rode, 1942] \\
\hline \multirow[t]{9}{*}{ H. lar } & 1 & 199 (or less) & Voss [1970] \\
\hline & 1 & ca. 205 & Poglayen-Neuwall [1977] \\
\hline & $51(?)$ & $210(\mathrm{R}=190-218)$ & Kollias and Kawakami [1981] \\
\hline & 1 & $210-217$ & Ellefson [1974, p. 91f] \\
\hline & 6 & ca. 210 & Martin et al. [1979] \\
\hline & 1 & $208-216$ & Robinson [1925] \\
\hline & 1 & 215 & Crandall [1964, p. 131] \\
\hline & 1 & 222 & Kollias and Kawakami [1981] \\
\hline & ? & 225 & Eisenberg [1981] \\
\hline \multirow[t]{2}{*}{ H. muelleri } & 1 & 195 & Brody and Brody [1974]b \\
\hline & 1 & 210 (or less) & Linke [1988]c \\
\hline H. pileatus and H. lar (?) & 4 & $183-221$ & Breznock et al. [1979] \\
\hline \multirow[t]{2}{*}{ H. pileatus } & 2 & 193 & $\begin{array}{l}\text { Dr. C.R. Schmidt [pers. comm.], } \\
\text { Schmidt-Pfister [1984] }\end{array}$ \\
\hline & 1 & (ca. $71 / 2$ months) & Badham [1967] \\
\hline \multirow[t]{10}{*}{ H. syndactylus ${ }^{\mathrm{d}}$} & 1 & 199 & Dr. C.R. Schmidt [pers. comm.] \\
\hline & 1 & $189-219$ & Dr. C.R. Schmidt [pers. comm.] \\
\hline & 1 & 200 (premature) & La Malfa [1969] \\
\hline & 1 & 221 (or less) & Dr. C.R. Schmidt [pers. comm.] \\
\hline & ? & 223 & Eisenberg [1981] \\
\hline & 1 & 230 & Hill [1967], La Malfa [1969] \\
\hline & 1 & 231 & Hill [1967], La Malfa [1969] \\
\hline & 1 & 235 & Hill [1967], La Malfa [1969] \\
\hline & 1 & 238 & La Malfa [1969] \\
\hline & 1 & 239 & La Malfa [1969] \\
\hline
\end{tabular}

a The gestation length reported by Olivier [cited in Rode, 1942] was observed on the colony of crested gibbons held at Clères Zoo (France). Although these gibbons have been published as H. leucogenys leucogenys [Delacour, 1934; Rode, 1942], at least some of them (males and juvenile females) should probably be identified as $H$. l. siki, to judge from the published photographs [Delacour, 1934, pp. 7 and 12; Rode, 1942, fig. 1]. This is a subspecies only later defined by Delacour [1951].

b Brody and Brody [1974] reported that "this gestation period was exactly 210 days, reckoned from the first day of the last menstruation". As this female's regular estrus averaged 31 days [Brody and Brody, 1974] and as other gibbons have been reported to cycle approximately every 27-30 days [King \& Mitchell, 1987], I subtract 15 days and use a gestation of 195 days.

c These gibbons have previously been identified as H. moloch [e.g. Linke, 1988; Ritscher \& Linke, 1982; Tembrock, 1974]. I visited the breeding male and the two surviving female offspring of the pair. On the basis of vocalizations and fur coloration, the male can be identified as $H$. muelleri abbotti. The breeding female died before my visit. Based on photographs kindly made available to me by Dr. K. Linke, this female can also be identified as $H$. muelleri, possibly $H$. muelleri funereus, certainly not $H$. muelleri abbotti. Based on fur coloration and vocalization, the offspring of the pair can be identified as $H$. muelleri.

$\mathrm{d}$ Whereas the gestation lengths provided by Schmidt [pers. comm.] cluster around 210 days, those reported by Hill [1967] and La Malfa [1969] are close to 235 days. It seems unlikely that the two estimates are compatible with each other. The difference between them is close to the suggested cycle length of about 30 days for the siamang [King \& Mitchell, 1987]. It is possible that the onset of gestation occurred one cycle length earlier than recorded in the shorter estimates, or otherwise one cycle length later than recorded in the longer estimates. The latter interpretation seems more probable, since at least one of the shorter estimates is based on a pair which was together for only 221 days before giving birth [Schmidt, pers. comm.]. 
results of the seven case reports of the present study have been summarized in Table III. Additional information on cases No. 2 and 6 can be found in Schmidt [in press] and Merz [1987], respectively.

\section{DISCUSSION}

Table I lists previously published data on the age of gibbons at the birth of first offspring. These data, after subtraction of gestation length (Table II), give information about the age at attainment of sexual maturity in gibbons. Most of the data fit well with the traditional view that gibbons usually become sexually mature somewhere between 6 and 8 years of age, and the siamang (H. syndactylus), at about 8 to 9 years. However, in most previously reported cases the exact age of the maturing animals was not known and had to be estimated (see Table I).

Seven case reports are summarized in Table III. These cases show that, under certain circumstances at least, gibbons can reach sexual maturity by 5 years of age in captivity (or even at 4 years in one case). This is much earlier than one would expect from previous data on the onset of fertility in gibbons.

Monogamous mammals and birds frequently exhibit a characteristic pattern of social, behavioral, ecological, and morphological features [e.g. Farabaugh, 1982; Kleiman, 1977; Kunkel, 1974]. Gibbons have been reported to show a similar complex of characteristics [MacKinnon \& MacKinnon, 1984; Raemaekers \& Chivers, 1980]. However, one characteristic has never been reported for gibbons as yet. It has been suggested that one of the features common to many monogamous species is a long maturation period of the young [Kleiman, 1977] and delayed sexual maturation of juveniles when they remain with the family group: “...inhibition of reproduction after the age of sexual maturity is common in juveniles remaining with the adults in the artificial conditions of captivity" [Kleiman, 1977, p.41]. Inhibition of reproduction in gibbons has not been reported to date, although a few observations have been made suggesting a delay in social maturity of gibbons retained in the natal group [Raemaekers \& Chivers, 1980, p.294].

In the wild, the timing of emigration from the natal gibbon group may depend on the availability of space and unmated individuals [Chivers \& Raemaekers, 1980], but aggressive parental behavior and the number of younger siblings may also be important determinants. Such factors might also help to explain the differences in the age of sexual maturity observed in gibbons.

Monogamy is a relatively rare social pattern among mammals [e.g. Kleiman, 1977]. Bischof [1972, 1975] proposed two different mechanisms which could maintain reproductive monopoly by the parents: (1) The offspring leave the group at attainment of sexual maturity or are driven away by the parents. (2) The offspring remain with the family group for some time after attainment of sexual maturity, but are excluded from propagation by their parents. Thus, social inhibition of reproduction should be expected to occur in those species following the second type of monogamy, whereas gibbons are thought to typify the first mechanism (e.g. Anzenberger, 1985; Bischof, 1972, 1975).

Although it is uncertain whether or not callitrichids are monogamous [see e.g. review by Goldizen, 1987], social inhibition of reproduction has been found to occur in laboratory groups of several species of callitrichid monkeys, including Callithrix jacchus, Saguinus fuscicollis, and S. oedipus. These studies have demonstrated that social environment influences fertility, sociosexual behavior, and pair bond formation in these species. The presence of the father or of another reproductive male may inhibit mating in a subordinate male [Abbott, 1984; French et al., 1984], while the presence of the mother or of another reproductive female may inhibit sexual behavior in a subordinate female, and even suppress ovulation 


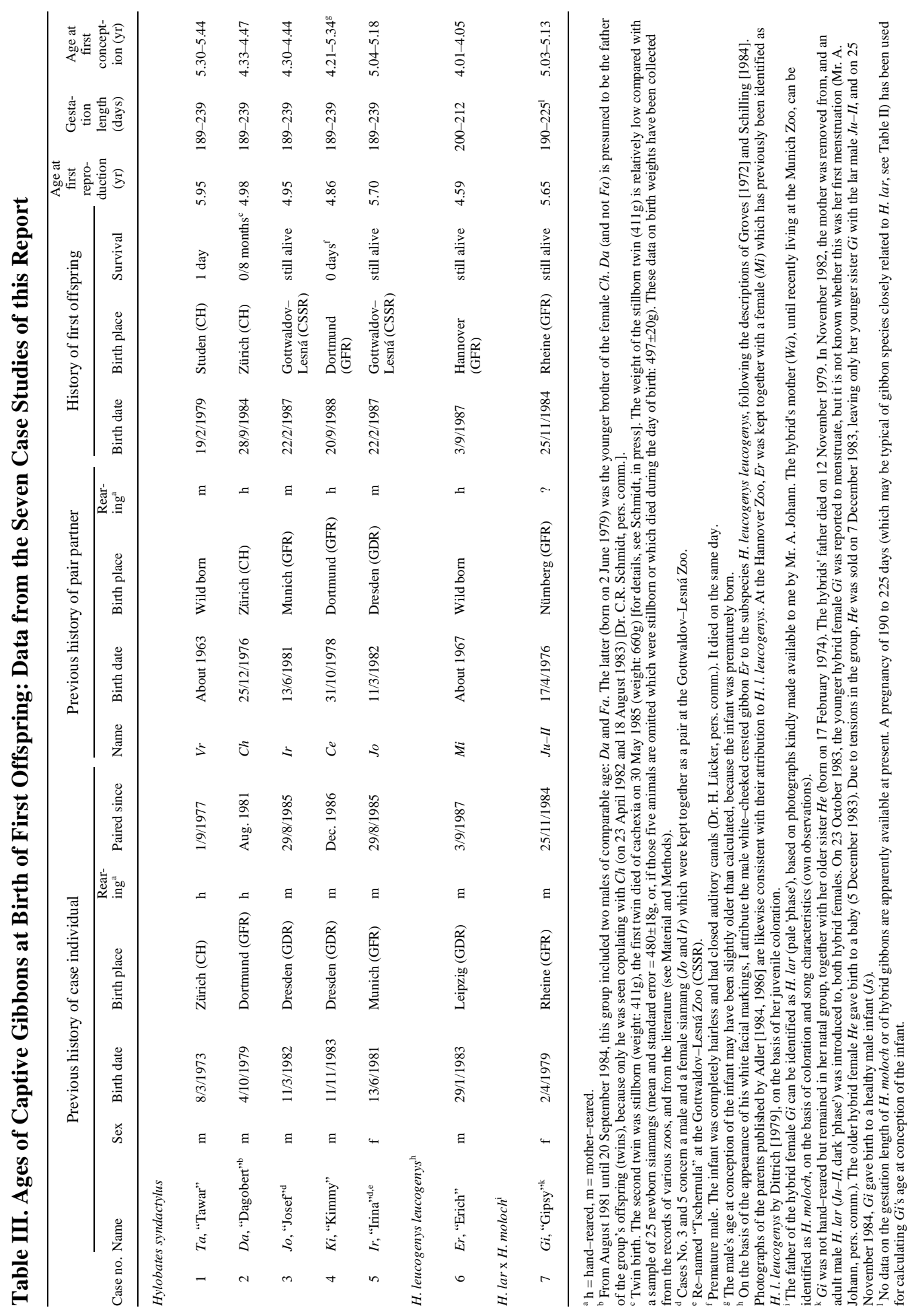


[Abbott, 1984; Abbott \& Hearn, 1978; Abbott et al., 1981; Epple \& Katz, 1984; French et al., 1984; Savage et al., 1988; Tardif, 1984]. Subordinate animals are apparently released from this social suppression or inhibition of sexual behavior (and fertility) when they are removed and housed with an adult animal of the opposite sex. In addition, it has been be shown that maturing tamarins (males and females of Saguinus fuscicollis and females of $S$. oedipus) can fulfill the behavioral roles of pair bonded adults and also breed at a much earlier age when they live under the influence of an adult sex partner, in comparison with animals cohabiting with a sex partner of their own age [Epple, 1981; Epple \& Katz, 1980], or remaining in their family group [Tardif, 1984].

It may, therefore, be significant that four of the gibbons presented in the case reports of this study had been separated from their natal group, and had, at a relatively young age, been brought together with a much older potential mate (case reports 1, 2, 4, 6). However, in one pair of captive siamangs, both animals had been mother-reared, both had been brought together at an early age (before the age of five years), and both became sexually mature well before the age of six years (case reports 3 and 5). The seventh case concerns a young female whose parents had been removed from the natal group, while a strange adult male had been introduced. The male formed a breeding pair with that female's older sister, but as soon the older sister had been removed, the young female started breeding with the same male.

Two different social variables could possibly have influenced the early sexual maturity in the cases presented here: 1 . The disruption of the family unit and removal of parental pressure, and 2. the appearance of a strange social stimulus.

It has been suggested that chemical stimuli found in the scent secretions produced by the natal family are most likely involved in reproductive suppression in tamarins. This potential role of scent secretions is supported by the observation that scent markings from the natal family have the ability to disrupt reproductive cycles in Saguinus fuscicollis [Epple \& Katz, 1984] and to delay the onset of ovulations in newly paired females of $S$. oedipus [Savage et al., 1988]. In this context, it may be relevant that the presence of a scent gland has recently been discovered in the siamang (Hylobates syndactylus) [Geissmann, 1987a], and macroscopically similar glandular structures seem to be present in (perhaps all) other gibbon species [Geissmann, 1987b; Mootnick et al., 1987].

However, social factors influencing the onset of sexual maturity in gibbons cannot securely be demonstrated from these data. Early sexual maturation in the case studies presented above could also have been the result of a third variable: better nutrition of these animals. In baboons, macaques and chimpanzees, the age at attainment of developmental markers such as the age of first reproduction may occur much earlier in captive or provisioned than in unprovisioned wild animals [e.g. Altmann et al., 1981; Sugiyama \& Ohsawa, 1982; Tutin \& McGinnis, 1981]. For instance, in yellow baboons (Papio cynocephalus), "the ratio of age at attainment of developmental milestones for animals in captivity to that for unprovisioned wild animals was approximately 3.5 to 5 " [Altmann \& Alberts, 1987].

Thus, three different variables may have influenced the early sexual maturity of the gibbons studied here: early removal from the family group, early confrontation with a suitable mate, and boosted nutrition. The variables could not be experimentally controlled in this purely descriptive study. Therefore, it cannot be decided which of the three variables may have been responsible for the early sexual maturity reported here. Each variable seems plausible to some degree.

If one of these variables (no matter which one) can speed up sexual maturation by about 1 to 3 years in gibbons, this holds some promise for breeding these 


\section{8 / Geissmann}

animals in captivity. Because of the strictly monogamous social structure of most species, adult gibbons must usually be kept in pairs. In addition, due to their low reproductive potential, "gibbons cannot be perpetuated in significant numbers artificially, despite attempts to do so. Their maximum reproductive rate is low (about one offspring per every 1-2 years), and many individuals will not reproduce in captivity. Even if captive populations could replace themselves (some zoos have had good success), any margin of increase would be extremely low and unsteady" [Brockelman, 1975, p. 149].

Lowering the age at first reproduction would mean not only one additional offspring per breeding pair, but also that the offspring can breed earlier. Hence, a geometrical shift in the pattern of population increase could result. This would represent a significant improvement in the breeding success of the captive gibbon population, thus reducing the demand for animals captured from the fast-diminishing wild populations, some of which have already, or very nearly, reached relict status [Brockelman \& Chivers, 1984; Chivers, 1986; MacKinnon, 1986, 1987; MacKinnon \& MacKinnon, 1987].

\section{CONCLUSIONS}

1. Virtually without exception, data collected from the literature support the traditional view that gibbons, both in the wild and in captivity, usually become sexually mature somewhere between 6 and 8 years of age, and the siamang (H. syndactylus), at about 8 to 9 years. However, in most previously reported cases the exact age of the maturing animals was not known and had to be estimated.

2. This study presents seven case reports on captive gibbons of known age. Captive males of the white-cheeked crested gibbon (H. leucogenys leucogenys) and of the siamang (H. syndactylus) can breed at the age of 4 and 4.3 years, respectively. Similarly, hybrid females (H. lar x H. moloch) and siamang females can breed at 5.1 and 5.2 years, respectively. This is much earlier than one would expect from previous data on the onset of fertility in gibbons.

3. It is not known whether gibbons reach sexual maturity earlier in captivity or whether sexual maturity is also reached by five years of age in the wild.

4. Relative to earlier case studies, three different variables could possibly have influenced the age at sexual maturity in the cases presented here: 1) The disruption of the family unit and removal of parental pressure, 2) the appearance of a strange social stimulus, and 3) high quality nutrition.

5. The maximum reproductive rate of gibbon pairs is relatively low (about one offspring per every 1-2 years, but rather 2-3 years in the wild). Lowering the age at first reproduction would not only mean one additional offspring per breeding pair, but that the offspring could also breed earlier, resulting in a geometrical modification of the pattern of population increase. This would represent a significant improvement in the breeding success of the captive gibbon population, thus reducing the demand for animals to be removed from threatened wild populations.

\section{ACKNOWLEDGMENTS}

I wish to thank the officials of the zoos of Dortmund (Dr. W. Bartmann and Dr. H. Lücker), Hannover (Dr. G. Merz and Mr. R. Wolf), Rheine (Dr. W. Salzert and Mr. A. Johann), Studen (Mr. H. Steiner and Mr. H.-J. Dietrich) and Zürich (Dr. P. Weilenmann and Dr. C. R. Schmidt) for permission to study the animals in their care and for useful information about the animals' previous history. Additional information on the gibbons of this study were kindly provided by Dr. J. Frolka (Gottwaldov-Lesná Zoo), Mr. W. Gensch 
(Dresden Zoo), and Mrs. S. Landgraf (Zoo Hellabrunn, Munich). For information on siamang birth weights, I am most grateful to Dr. W. Encke and Ms. B. Sattler (Krefeld Zoo), Ms. S. Fowmes (Twycross Zoo), Mr. S. LaMalfa (Milwaukee Zoo), Dr. H. Lücker (Dortmund Zoo), Mathias Orgeldinger (Frankfurt), Dr. C.R. Schmidt (Zürich Zoo), and Mrs. E. Schramke (Duisburg Zoo). I am particularly indebted to Prof. R.D. Martin, Drs. Gustl Anzenberger, Steve Ferrari, Christopher Pryce, Caroline Ross, and three anonymous reviewers for reading and commenting upon earlier drafts of this manuscript.

\section{REFERENCES}

Abbott, D.H. Behavioral and physiological suppression of fertility in subordinate marmoset monkeys. AMERICAN JOURNAL OF PRIMATOLOGY 6:169-186, 1984.

Abbott, D.H.; Hearn, J.P. Physical, hormonal and behavioural aspects of sexual development in the marmoset monkey, Callithrix jacchus. JOURNAL OF REPRODUCTION AND FERTILITY 53:155-166, 1978.

Abbott, D.H.; McNeilly, A.S.; Lunn, S.F.; Hulme, M.J.; Burden, F.J. Inhibition of ovarian function in subordinate female marmoset monkeys (Callithrix jacchus jacchus). JOURNAL OF REPRODUCTION AND FERTILITY 653:335-345, 1981.

Adler, J. Gibbons - Luftakrobaten in unserem Zoo. PANTHERA, MITTEILUNGEN AUS DEM ZOOLOGISCHEN GARTEN LEIPZIG 1984:18-21, + 2 plates, 1984

Adler, J. Ein drammatisches Ereignis auf der Gibboninsel. PANTHERA, MITTEILUNGEN AUS DEM ZOOLOGISCHEN GARTEN LEIPZIG 1986:26-28, + 1 plate, 1986.

Adler, J.; Ruckhäberle, K.-E.; Schlegel, L.; Elze, K. Wiederholte Plazentaretention bei einem Schopfgibbon (Hylobates concolor leucogenys Ogilby, 1840) im Zoologischen Garten Leipzig. DER ZOOLOGISCHE GARTEN (N.F.) 58:198-204, 1988.

Altmann, J.; Alberts, S. Body mass and growth rates in a wild primate population. OECOLOGIA 72:15-20, 1987.

Altmann, J.; Altmann, S.; Hausfater, G. Physical maturation and age estimates of yellow baboons, Papio cynocephalus, in Amboseli National Park, Kenya. AMERICAN JOURNAL OF PRIMATOLOGY 1:389-399, 1981.

Anonymous. Bright-eyed holly siamang. ZOONOOZ (San Diego) 49(1):10, 1976.

Anzenberger, G. How stranger encounters of common marmosets (Callithrix jacchus jacchus) are influenced by family members: the quality of behavior. FOLIA PRIMATOLOGICA 45:204-224, 1985.

Badham, M. A note on breeding the pileated gibbon Hylobates lar pileatus at Twycross Zoo. INTERNATIONAL ZOO YEARBOOK 7:92-93. London, 1967.
Bartmann, W.; Brahm, E. Psychopathisches Brutpflegeverhalten bei Siamangs (Symphalangus syndactylus Raffles, 1821). Pp. 195-197 in VERHANDLUNGSBERICHT DES XXII. INTERNATIONALEN SYMPOSIUMS ÜBER DIE ERKRANKUNGEN DER ZOOTIERE, ARNHEM 1980. Berlin, Akademie-Verlag, 1980.

Bennett, J. A summary on maintaining a breeding pair of siamangs in captivity. INTERNATIONAL ZOO NEWS 23(7):22-25, 1976.

Bischof, N. Inzuchtbarrieren in Säugetiersozietäten. HOMO 23:330-351, 1972.

Bischof, N. Comparative ethology of incest avoidance. Pp. 37-67 in BIOSOCIAL ANTHROPOLOGY. ASA STUDIES, VOL. 1. R. Fox, ed. London, Malaby Press, 1975.

Breznock, A.W.; Porter, S.; Harrold, J.B.; Kawakami, T.G. Hand-rearing infant gibbons. Pp. 287-298 in NURSERY CARE OF NONHUMAN PRIMATES. G.C. Ruppenthal; D.J. Reese, eds. London, Plenum Press, 1979.

Brockelman, W.Y. Gibbon populations and their conservation in Thailand. NATURAL HISTORY BULLETIN OF THE SIAM SOCIETY 26:133-157, 1975.

Brockelman, W.Y.; Chivers, D.J. Gibbon conservation: Looking to the future. Pp. $3-12$ in THE LESSER APES: EVOLUTIONARY AND BEHAVIOURAL BIOLOGY. H. Preuschoft; D.J. Chivers; W.Y. Brockelman; N. Creel, eds. Edinburgh, Edinburgh University Press, 1984.

Brody, E.J.; Brody, A.E. Breeding Müller's Bornean gibbon Hylobates lar muelleri. INTERNATIONAL ZOO YEARBOOK 14:110-113. London, 1974.

Chivers, D.J. The siamang in Malaya: A field study of a primate in tropical rain forest. CONTRIBUTIONS TO PRIMATOLOGY, VOL. 4. S. Karger, Basel, 1974.

Chivers, D.J. Southeast Asian primates. Pp. 127-151 in PRIMATES: THE ROAD TO SELF-SUSTAINING POPULATIONS. K. Benirschke, ed. New York, Springer-Verlag, 1986.

Chivers, D.J.; Raemaekers, J.J. Long-term changes in behaviour. Pp. 209-269 in MALAYAN FOREST PRIMATES: TEN 


\section{2 / Geissmann}

YEARS' STUDY IN TROPICAL RAIN FOREST. D.J. Chivers, ed. London, Plenum Press, 1980.

Crandall, L.S. MANAGEMENT OF WILD MAMMALS IN CAPTIVITY. London, The University of Chicago Press, 1964.

Dao Van Tien. On the north Indochinese gibbons (Hylobates concolor) (Primates: Hylobatidae) in North Vietnam. JOURNAL OF HUMAN EVOLUTION 12:367-372, 1983.

Delacour, J. Les Gibbons Indochinois. LA TERRE ET LA VIE, PARIS 4(1):1-12, 1934.

Delacour, J. La systématique des Gibbons Indochinois. MAMMALIA 15:118-123, 1951.

Deputte, B.L.; Leclerc-Cassan, M. Sex determination and age estimation in the whitecheeked gibbon Hylobates concolor leucogenys: anatomical and behavioural features. INTERNATIONAL ZOO YEARBOOK 21:187-193. London, 1981.

Dittrich, L. Jugendentwicklung, Geschlechtsreife und Wechsel der Färbung des Haarkleides beim Schopfgibbon (Hylobates concolor leucogenys). BIJDRAGEN TOT DE DIERKUNDE (CONTRIBUTIONS TO ZOOLOGY), AMSTERDAM 49:247-254, 1979.

Dobroruka, L.J. Prebarvování gibona kápového, Hylobates pileatus Gray, 1861. - Colour transformation in the pileated gibbon, Hylobates pileatus Gray, 1861. GAZELLA (Zoo Praha) 2 (2):63-65, 1979 (Czech and English).

Eisenberg, J.F. THE MAMMALIAN RADIATIONS: AN ANALYSIS OF TRENDS IN EVOLUTION, ADAPTATION, AND BEHAVIOR. Chicago, University of Chicago Press, 1981.

Ellefson, J.O. A natural history of white-handed gibbons in the Malayan Peninsula. Pp. 1-136 in GIBBON AND SIAMANG, VOL. 3. D.M. Rumbaugh, ed. Basel, Switzerland, S. Karger, 1974.

Epple, G. Effect of pair-bonding with adults on the ontogenetic manifestation of aggressive behavior in a primate, Saguinus fuscicollis. BEHAVIORAL ECOLOGY AND SOCIOBIOLOGY 8:117-123, 1981.

Epple, G.; Katz, Y. Social influences on first reproductive successs and related behaviors in the saddle-back tamarin (Saguinus fuscicollis, Callitrichidae). INTERNATIONAL JOURNAL OF PRIMATOLOGY 1:171-183, 1980.

Epple, G.; Katz, Y. Social influences on estrogen excretion and ovarian cyclicity in saddle back tamarins (Saguinus fuscicollis). AMERICAN JOURNAL OF PRIMATOLOGY 6:215-227, 1984.

Farabaugh, S.M. The ecological and social significance of duetting. Pp. 85-124 in ACOUSTIC COMMUNICATION IN BIRDS,
VOL. 2. D.E. Kroodsma; E.H. Miller; H Ouellet, eds. London, Academic Press, 1982.

Fischer, W. Einige Ergänzungen zur Haltung und Entwicklung des Schopfgibbons, Hylobates [Nomascus] concolor (Harlan). MILU, BERLIN 5:167-193, 1980.

Fox, G.J. Some comparisons between siamang and gibbon behaviour. FOLIA PRIMATOLOGICA 18:122-139, 1972.

Fox, G.J. SOCIAL DYNAMICS IN SIAMANG. Doctoral dissertation, University of Wisconsin Milwaukee, 1977.

Fox, G.J. Food transfer in gibbons. Pp. 324-332 in THE LESSER APES: EVOLUTIONARY AND BEHAVIOURAL BIOLOGY. H. Preuschoft; D.J. Chivers; W.Y. Brockelman; N. Creel, eds. Edinburgh, Edinburgh University Press, 1984.

French, J.A.; Abbott, D.H.; Snowdon, C.T. The effect of social environment on estrogen excretion, scent marking, and sociosexual behavior in tamarins (Saguinus oedipus). AMERICAN JOURNAL OF PRIMATOLOGY 6:155-167, 1984.

Geissmann, T. Mate change enhances duetting activity in the siamang gibbon (Hylobates syndactylus). BEHAVIOUR 96:17-27, 1986.

Geissmann, T. A sternal gland in the siamang gibbon (Hylobates syndactylus). INTERNATIONAL JOURNAL OF PRIMATOLOGY 8:1-15, 1987a.

Geissmann, T. Occurrence of sternal and axillary glands in hominoids. CHEMICAL SENSES 12:177-178, 1987b (Abstract only).

Geissmann, T. Funktion der gesanglichen Lautäusserungen des Siamangs, Hylobates syndactylus, mit besonderer Berücksichtigung der Paarbindungshypothese. DER ZOOLOGISCHE GARTEN (N.F.), in press.

Gittins, S.P.; Raemaekers, J.J. Siamang, lar and agile gibbons. Pp. 63-105 in MALAYAN FOREST PRIMATES: TEN YEARS' STUDY IN TROPICAL RAIN FOREST. D.J. CHIVERS. New York and London, Plenum Press, 1980.

Goldizen, A.W. Tamarins and marmosets: Communal care of offspring. Pp. $34-43$ in PRIMATE SOCIETIES. B.B. Smuts; D.L. Cheney; R.M. Seyfarth; R.W. Wrangham; T.T. Struhsaker, eds. Chicago and London, University of Chicago Press, 1987.

Goodall, J. THE CHIMPANZEES OF GOMBE. PATTERNS OF BEHAVIOR. Cambridge, The Belknap Press of Harvard University Press, 1986.

Gray, J.E. List of mammalia, tortoises and crocodiles collected by M. Mouhot in Camboja. PROCEEDINGS. ZOOLOGICAL SOCIETY OF LONDON 1861:135-140, 1861. 


\section{2 / Geissmann}

Groves, C.P. Systematics and phylogeny of gibbons. Pp. 1-89 in GIBBON AND SIAMANG, VOL. 1. D.M. Rumbaugh, ed. Basel, Switzerland, S. Karger, 1972.

Haggard, V.D. Lar gibbon, Hylobates lar, breeding records. INTERNATIONAL ZOO YEARBOOK 5:110-111. London, 1965.

Haimoff, E.H. Video analysis of siamang (Hylobates syndactylus) songs. BEHAVIOUR 76:128-151, 1981.

Hill, C. A. A note on the gestation period of the siamang Hylobates syndactylus. INTERNATIONAL ZOO YEARBOOK 7:93-94. London, 1967.

Kawakami, T.G.; Kollias, G.V. Breeding and rearing lar gibbons in captivity. Pp. 44-50 in THE LESSER APES: EVOLUTIONARY AND BEHAVIOURAL BIOLOGY. H. Preuschoft; D.J. Chivers; W.Y. Brockelman; N. Creel, eds. Edinburgh, Edinburgh University Press, 1984.

King, N.E.; Mitchell, G. Breeding primates in zoos. Pp. 219-261 in COMPARATIVE PRIMATE BIOLOGY, VOL. 2B: BEHAVIOR, COGNITION, AND MOTIVATION. G. Mitchell; J. Erwin, eds. New York, Alan R. Liss, 1987.

Kleiman, D.G. Monogamy in mammals. THE QUARTERLY REVIEW OF BIOLOGY 52:39-69, 1977.

Kollias, G.V.; Kawakami, T.G. Factors contributing to the successful captive reproduction of white-handed gibbons (Hylobates lar). AMERICAN ASSOCIATION OF ZOO VETERINARIANS, ANNUAL PROCEEDINGS 1981:45-47, 1981.

Kunkel, P. Mating systems of tropical birds: The effects of weakness or absence of external reproduction-timing factors, with special reference to prolonged pair bonds. ZEITSCHRIFT FÜR TIERPSYCHOLOGIE 34:265-307, 1974

LaMalfa, S. Trials and tribulations of captive siamangs at Milwaukee County Zoo. INTERNATIONAL ZOO NEWS 17:275-277, 1969.

Linke, K. Beobachtungen zur Entwicklung von 3 Gibbons bei einer Handaufzucht und 2 kombinierten Aufzuchten. DER ZOOLOGISCHE GARTEN (N.F.) 58:229-250, 1988).

Lister, R.E. Evaluation of fertility in male baboons (Papio cynocephalus), pp. 183-188 in BREEDING SIMIANS FOR DEVELOPMENTAL BIOLOGY. LABORATORY ANIMAL HANDBOOKS NO. 6. F.T. Perkins; P.N. O'Donoghue, eds. London, Laboratory Animals Ltd., 1975.

Ma, S.; Wang, Y. [The taxonomy and distribution of the gibbons in southern China and its adjacent region - with description of three new subspecies]. ZOOLOGICAL RESEARCH 7:393-410, 1986 (in Chinese, English summary).
Ma, S.; Wang, Y.; Poirier, F.E. Taxonomy, distribution, and status of gibbons (Hylobates) in southern China and adjacent areas. PRIMATES 29:277-286, 1988.

MacKinnon, J.R.; MacKinnon, K.S. Territoriality, monogamy and song in gibbons and tarsiers. Pp. 291-297 in THE LESSER APES: EVOLUTIONARY AND BEHAVIOURAL BIOLOGY. H. Preuschoft; D.J. Chivers; W.Y. Brockelman; N. Creel, eds. Edinburgh, Edinburgh University Press, 1984.

MacKinnon, J.R.; MacKinnon, K.S. Conservation status of the primates of the IndoChinese subregion. PRIMATE CONSERVATION 8:187-195, 1987.

MacKinnon, K.S. The conservation status of nonhuman primates in Indonesia. Pp. 99-126 in PRIMATES: THE ROAD TO SELFSUSTAINING POPULATIONS. K. Benirschke, ed. New York, Springer-Verlag, 1986.

MacKinnon, K.S. Conservation status of primates in Malesia, with special reference to Indonesia. PRIMATE CONSERVATION 8:175-183, 1987.

Marshall, J.; Sugardjito, J. Gibbon systematics. Pp. 137-185 in COMPARATIVE PRIMATE BIOLOGY, VOL. 1: SYSTEMATICS, EVOLUTION, AND ANATOMY. D.R. Swindler; J. Erwin. New York, Alan R. Liss, 1986.

Martin, D.P.; Golway, P.L.; George, M.J.; Smith, J.A. Care of the infant and juvenile gibbon (Hylobates lar). Pp. 287-298 in NURSERY CARE OF NONHUMAN PRIMATES. G.C. Ruppenthal; D.J. Reese, eds. New York and London, Plenum Press, 1979.

McCann, C. Notes on the colouration and habits of the white-browed gibbon or hoolock (Hylobates hoolock Harl.). JOURNAL OF THE BOMBAY NATURAL HISTORY SOCIETY 36:395-405, 1933.

Merz, G. Flaschenkind Lena - von der Gibbonmutter verlassen. DER ZOOFREUND (ZEITSCHRIFT DER ZOOFREUNDE HANNOVER E.V.) 66:14-16, 1987.

Meyer-Holzapfel, M. Beobachtungen über das Verhalten einer Gibbonfamilie im Zürcher Zoologischen Garten. DER ZOOLOGISCHE GARTEN (N.F.) 17:10-27, 1950.

Mootnick, A.R.; Haimoff, E.H.; Nyunt-Lwin, K. Conservation and captive management of hoolock gibbons in the Socialist Pepublic of the Union of Burma. AAZPA (American Association of Zoological Parks and Aquariums) ANNUAL CONFERENCE PROCEEDINGS 1987:1-27, 1987.

Peart, J.F. Notes on the colouration of the whitebrowed gibbon (H. hoolock Harl.). JOURNAL OF THE BOMBAY NATURAL HISTORY SOCIETY 37:214, 1935. 


\section{2 / Geissmann}

Pocock, R.I. Observations upon a female specimen of the Hainan gibbon (Hylobates hainanus), now living in the Society's gardens. PROCEEDINGS. ZOOLOGICAL SOCIETY OF LONDON 1905 (2):169-180, 1905.

Poglayen-Neuwall, I. Parturition in a handreared, primiparous gibbon (Hylobates lar). DER ZOOLOGISCHE GARTEN (N.F.) 47:57-58, 1977.

Raemaekers, J.J.; Chivers, D.J. Socio-ecology of Malayan forest primates. Pp. 279-316 in MALAYAN FOREST PRIMATES: TEN YEARS' STUDY IN TROPICAL RAIN FOREST. D.J. Chivers, ed. London, Plenum Press, 1980.

Richard, A.F. PRIMATES IN NATURE. New York, Freeman, 1985.

Ritscher, D; Linke, K. Wiederholter Kaiserschnitt bei einem Silbergibbon (Hylobates moloch) und veterinärmedizinische Probleme bei der Aufzucht der beiden Jungtiere. Pp. 107-111 in VERHANDLUNGSBERICHT DES XXIV. INTERNATIONALEN SYMPOSIUMS ÜBER DIE ERKRANKUNGEN DER ZOOTIERE, VESZPRÉM 1982. Berlin, Akademie-Verlag, 1982.

Robinson, S.M. Birth of a white-handed gibbon (Hylobates lar) in captivity. JOURNAL OF THE BOMBAY NATURAL HISTORY SOCIETY 30:456-458, 1925.

Rode, P. A propos de la durée de gestation chez les Gibbons. MAMMALIA 6:46-47, 1942.

Rowell, T.E. Variation in age at puberty in monkeys. FOLIA PRIMATOLOGICA 27:284-296, 1977.

Rumbaugh, D.M. The siamang infant, Sarah... its growth and development. ZOONOOZ (San Diego) 40 (3):12-18, 1967.

Savage, A.; Ziegler, T.E.; Snowdon, C.T. Sociosexual development, pair bond formation, and mechanisms of fertility suppression in female cotton-top tamarins (Saguinus oedipus oedipus). AMERICAN JOURNAL OF PRIMATOLOGY 14:345-359, 1988.

Sawina, N.W.; Opachowa, W.R. Haltung und Zucht von Weisshandgibbons (Hylobates lar L., 1771) im Leningrader Zoo. DER ZOOLOGISCHE GARTEN (N.F.) 51:343-352, 1981.

Schessler, T.; Nash, L.T. Food sharing among captive gibbons (Hylobates lar). PRIMATES 18:677-689, 1977.

Schilling, D. Gibbons in European zoos, with notes on the identification of subspecies of concolor gibbon. Pp. 51-60 in THE LESSER
APES: EVOLUTIONARY AND BEHAVIOURAL BIOLOGY. H. Preuschoft; D.J. Chivers; W.Y. Brockelman; N. Creel, eds. Edinburgh, Edinburgh University Press, 1984. Schmidt, C.R. Twin births in siamang (Symphalangus syndactylus). INTERNATIONAL ZOO NEWS (in press).

Schmidt-Pfister, A. Ili, der kleine Kappengibbon. IRBIS, TIERGARTEN-GESELLSCHAFT ZÜRICH, BULLETIN 1:3, 1984.

Schultz, A.H. Polydactylism in a siamang. FOLIA PRIMATOLOGICA 17:241-247, 1972.

Steiner, H. Gibbons. Pp. 5-6 in UNSERE TIERE. EIN SAMMELWERK FÜR NATURUND TIERFREUNDE, VOL. 1. Zürich, Beringer \& Pampaluchi, 1947.

Steiner, H. Beobachtungen über das brutbiologische Verhalten des Gibbons und an einem frühgeborenen Fötus bei einer Bastardzucht von Hylobates. ARCHIV DER JULIUS KLAUS-STIFTUNG FÜR VERERBUNGSFORSCHUNG, SOZIALANTHROPOLOGIE UND RASSENHYGIENE 24:217-236, 1949.

Sugiyama, Y.; Ohsawa, H. Population dynamics of Japanese monkeys with special reference to the effect of artificial feeding. FOLIA PRIMATOLOGICA 39:238-263, 1982.

Tardif, S.D. Social influences on sexual maturation of female Saguinus oedipus oedipus. AMERICAN JOURNAL OF PRIMATOLOGY 6:199-209, 1984.

Tembrock, G. Sound production of Hylobates and Symphalangus. Pp. 176-205 in GIBBON AND SIAMANG, VOL. 3. D.M. Rumbaugh, ed. Basel, Switzerland, S. Karger, 1974.

Tilson, R.L. Behaviour of hoolock gibbon (Hylobates hoolock) during different seasons in Assam, India. JOURNAL OF THE BOMBAY NATURAL HISTORY SOCIETY 76:1-16, 1979.

Tilson, R.L. Family formation strategies of Kloss's gibbons. FOLIA PRIMATOLOGICA 35:259-287, 1981

Tutin, C.E.G.; McGinnis, P.R. Chimpanzee reproduction in the wild. Pp. 239-264 in REPRODUCTIVE BIOLOGY OF THE GREAT APES. COMPARATIVE AND BIOMEDICAL PERSPECTIVES. C.E. Graham, ed. New York, Academic Press, 1981.

Voss, G. On the gestation of the white-handed gibbon or lar, Hylobates lar L. DER ZOOLOGISCHE GARTEN (N.F.) 39:295296, 1970. 